African Crop Science Journal by African Crop Science Society is licensed under a Creative Commons Attribution 3.0 Uganda License. Based on a work at www.ajol.info/ and www.bioline.org.br/cs DOI: https://dx.doi.org/10.4314/acsj.v29i4.4

\title{
PREVALENCE OF PLANT-PARASITIC NEMATODES IN RICE FIELDS IN GHANA
}

\section{S.T. NYAKU ${ }^{1}$, H. LUTUF ${ }^{1,2}$, J.O. HONGER ${ }^{3}$, A. DEDE ${ }^{1}$, F.C. BRENTU ${ }^{4}$, R. BENISSAN ${ }^{1}$, S. OSABUTEY ${ }^{1}$, V. LARBI ${ }^{1}$, E. KORANTENG ${ }^{1}$, C. AFUN ${ }^{1}$, M. OKYERE ${ }^{1}$ and F.K. ABLORMETI ${ }^{1,2}$}

${ }^{1}$ Department of Crop Science, School of Agriculture, College of Basic and Applied Sciences, University of Ghana, P. O. Box LG 44, Legon, Ghana

${ }^{2}$ Council for Scientific and Industrial Research- Oil Palm Research Institute, P. O. Box 74, Kade, Ghana

${ }^{3}$ Soil and Irrigation Research Centre, School of Agriculture, College of Basic and Applied Sciences, University of Ghana, P. O. Box LG 68. Legon, Ghana

${ }^{4}$ Forest and Horticultural Crops Research Centre (FOHCREC), College of Basic and Applied Sciences, University of Ghana, Kade, Ghana

Corresponding author: stnyaku@ug.edu.gh, seloame.nyaku@gmail.com

(Received 18 September 2020; accepted 12 November 2021)

\begin{abstract}
Rice (Oryza sativa L.) is one of the most cultivated crops worldwide whose production in sub-Saharan Africa is extensively affected by root nematodes. The objective of this study was to identify and establish the distribution of plant-parasitic nematodes (PPNs), in rice growing fields within different regions of Ghana. Soil and root samples were taken from rice fields, namely fourteen from Volta Region, eleven from the Soil and Irrigation Research Centre (SIREC), Kpong (Eastern Region); and five from Dawhenya (Greater Accra Region). The soil samples were taken from 0-30 cm depths, together with root samples. A total of twenty-four nematode genera were identified in soil and root samples from the three regions. These included: Aphelenchus spp., Belonolaimus spp., Ditylenchus spp., Dolichodorus spp., Helicotylenchus spp., Hemicriconemoides spp. Hemicycliophora spp. Heterodera spp., Hirschmaniella spp., Hoplolaimus spp., Longidorus spp., Meloidogyne spp., Paralongidorous spp., Paratylenchus spp., Pratylenchus spp., Radopholus spp., Rhabditida spp., Rotylenchulus spp., Scutellonema spp., Trichodorus spp., Tylenchornchus spp., Tylenchulus spp., Tylenchus spp. and Xiphinema spp. In the Volta Region, Tylenchus spp. was the most abundant $(29.01 \%)$ in the soil; while Meloidogyne spp. was most the abundant (36.86\%) in the roots. In Dawhenya regions, Meloidogyne spp. was the most abundant $(26.96 \%)$ in the soil; while Tylenchus spp. was the most abundant (25.94\%) in the roots. In the Eastern Region, Meloidogyne spp. was the most abundant (41.7\%) in the soil; while Pratylenchus spp. was the most abundant $(36.1 \%)$ in the roots. These nematodes threaten rice production in Ghana, if not managed well in farmer's fields.
\end{abstract}

Key Words: Meloidogyne spp., Oryza Sativa, Volta region 
Le riz (Oryza sativa L.) est l'une des cultures les plus cultivées au monde dont la production en Afrique subsaharienne est largement affectée par les nématodes des racines. L'objectif de cette étude était d'identifier et d'établir la répartition des nématodes phytoparasites (NPP) dans les rizières de différentes régions du Ghana. Des échantillons de sol et de racines ont été prélevés dans les rizières, à savoir quatorze de la région de la Volta, onze du Centre de Recherche sur les Sols et l'Irrigation (SIREC), Kpong (région de l'Est); et cinq de Dawhenya (région du Grand Accra). Les échantillons de sol ont été prélevés à des profondeurs de 0 à $30 \mathrm{~cm}$, ainsi que des échantillons de racines. Au total, vingt-quatre genres de nématodes ont été identifiés dans des échantillons de sol et de racines des trois régions. Ceux-ci comprenaient : Aphelenchus spp., Belonolaimus spp., Ditylenchus spp., Dolichodorus spp., Helicotylenchus spp., Hemicriconemoides spp. Hemicycliophora spp. Heterodera spp., Hirschmaniella spp., Hoplolaimus spp., Longidorus spp., Meloidogyne spp., Paralongidorous spp., Paratylenchus spp., Pratylenchus spp., Radopholus spp., Rhabditida spp., T. ., Tylenchornchus spp., Tylenchulus spp., Tylenchus spp. et Xiphinema spp. Dans la région de la Volta, Tylenchus spp. était le plus abondant (29,01\%) dans le sol; tandis que Meloidogyne spp. était le plus abondant $(36,86 \%)$ dans les racines. Dans les régions de Dawhenya, Meloidogyne spp. était le plus abondant $(26,96 \%)$ dans le sol; tandis que Tylenchus spp. était le plus abondant (25,94\%) dans les racines. Dans la région orientale, Meloidogyne spp. était le plus abondant $(41,7 \%)$ dans le sol; tandis que Pratylenchus spp. était le plus abondant $(36,1 \%)$ dans les racines. Ces nématodes menacent la production de riz au Ghana, s'ils ne sont pas bien gérés dans les champs des agriculteurs.

Mots Clés : Meloidogyne spp., Oryza Sativa, région de la Volta

\section{INTRODUCTION}

Rice (Oryza sativa $\mathrm{L}$ ) is the main food crop of more than half of the world population. In Ghana, however, rice production only meets $30-40 \%$ of the demand; thus the country greatly depends on massive rice imports. Moreover, rice production and its continuous intensification within the country, could impact plant-parasitic nematodes and their pest status (Coyne et al., 1999). More than 35 genera and 130 species of plant-parasitic nematodes (PPNs) have been associated with rice damage (Gerber et al., 1987); though only 29 species are known or suspected to cause significant yield loss (Bridge et al., 2005).

Plant-parasitic nematodes occur in almost all rice environments; they are diverse and their distributions span different between ecosystems (Prot and Rahman, 1994). In a survey by Udo et al. (2011) in South Eastern Nigeria, nematodes identified on rice included Heterodera spp., Hirschmaniella spp., and
Meloidogyne spp. Nematodes have also been found in rice fields in the Philippines (Pascual et al.,2014);including Aphelenchoides spp., Hirschmaniella spp., Meloidogyne spp., Criconematidae, Pratylenchus spp., Rotylenchulus spp., Rotylenchus spp., and Tylenchoryhnchus spp.

In a study conducted in Ghana on rice fields in the forest zone (Ashanti, Brong Ahafo, and Eastern Regions) and the savannah zone (Northern and Upper East Regions), a diversity of nematodes was reported (Coyne et al., 1999). Fifty-one species from 29 nematode genera were identified in 145 fields (upland, hydromorphic, rainfed lowland, and irrigated lowland ecosystems) within the savannah and forest agroecological zones. Within the upland/ hydromorphic rice fields Pratylenchus spp. consisted of about $80 \%$ and Ditylenchus spp. (78\%) as the most abundant nematode species. However, within the forest zone fields Coslenchus franklinae and Helicotylenchus spp., were most prevalent and consisted of 
84 and $76 \%$ of nematode species respectively. Hirschmanniella spp. were found in $100 \%$ of samples and were more prevalent in the savannah zone compared to other nematodes in lowland rice. However, within the forest zone Xiphinema bergeri consisted of $71 \%$ of nematodes identified in lowland rice (Coyne et al.,1999).

A number of land use changes have taken place in Ghana, which have involved intensification of agricultural production and the introduction of new technologies. These soil management changes may have contributed to shifts in the occurrence and density of nematode species, whose diversity, distribution and population densities need to be understood for proper rice production in Ghana. Therefore, objective of this study was to identify and establish the distribution of plant- parasitic nematodes (PPNs) in rice growing fields in three regions of Ghana.

\section{MATERIALS AND METHODS}

Study sites. The study was conducted in three regions of Ghana, namely, Greater Accra, Eastern and Volta. Fourteen locations were randomly selected from rice growing fields in seven rice-producing areas in the Volta region, namely Tsawornu, Akrofu, Sadzikorfe, Gbefi, Kpando, Ve-golokuati and Aveyime. Aveyime is under the production and management of the Aveyime rice project which has over 100 ha of rice fields within the Volta Region. The large hectare (ha) of land under cultivation in Aveyime provided basis for its division into 8 sites for sampling purposes. The soil types are tropical black clays (earths).

Eleven sites were also randomly selected at SIREC, Kpong in the Eastern region, a rice production centre under university of Ghana. The soil is clayey and is classified as a Typic Calcicustert (Amatekpor and Dowuona, 1995), a vertisol, deriving from garneticFerrous hornblende gneiss parent material. Five sites cultivated to rice in Dawhenya within the Greater-Accra region, were also sampled, and the soil types were tropical black clays (earths).

These areas have a tropical climate, characterised by moderate temperatures, 21$32^{\circ} \mathrm{C}$, for most of the year. The regions have two rainfall regimes in the year; the first is from March to July and the second is from mid-August to October. The Geographical Positioning System (GPS) for the various sampling sites is provided (Table 1).

Nematode extraction from soil. The sucrose-centrifugation method of nematode extraction was used; whereby 200 cubic centimeters of the soil sample was taken into a container and covered with water twice the volume of the soil. The soil and water were mixed uniformly and left to rest for 10minutes. The supernatant was poured through 20/500 mesh stacked sieves. The 500 mesh sieve was tapped gently to enhance drainage. The 20 mesh sieve trapped organic debris, while the 500 mesh sieve trappednematodes and silt. The soil left in the container was again covered with about $500 \mathrm{ml}$ of water, mixed uniformly and allowed to settle for 10 minutes, before being decanted through the above mentioned sieve. The latter process was repeated to ensure that all nematodes in the soil were recovered and trapped on the 500 mesh sieve. The soil particle containing the nematodes were guided to one end of the 500 mesh, sieve by rinsing other ends with water from the wash bottle. The contents were poured into a measuring beaker and then poured into a centrifuge tube. The contents in the centrifuge bottle were centrifuged at $1700 \mathrm{rmp}$ for 5 minutes, and the supernatant discharged, leaving the soil particles with nematodes. A 35 millimeter sugar solution was poured on the remaining soil particles of the centrifuge tube and centrifuged at $1000 \mathrm{rmp}$ for 1 minute. The sucrose solution with the nematodes was then poured onto the 500 mesh sieve tube sieve. The nematodes were thoroughly rinsed with water, to get rid of the sucrose. The nematodes in the remaining solution were washed gently 
TABLE 1. The Geographical Positioning System coordinates for thirty (30) sites from three Regions (Volta, Greater-Accra, and Eastern)

\begin{tabular}{|c|c|c|c|c|c|c|c|c|}
\hline \multirow[t]{2}{*}{ Region } & \multirow[t]{2}{*}{ Town } & \multirow[t]{2}{*}{ Site \# } & \multicolumn{3}{|c|}{ Latitude } & \multicolumn{3}{|c|}{ Longitude } \\
\hline & & & Degrees & Minutes & Seconds & Degrees & Miinutes & Seconds \\
\hline \multirow[t]{6}{*}{ Volta } & Tsawornu & Site 1 & 5 & 59 & 0.21 & 0 & 27 & 0.25 \\
\hline & Akrofu & Site 2 & 6 & 37 & 60 & 0 & 22 & 60 \\
\hline & Sadzikorfe & Site 3 & 7 & 0 & 0.8 & 0 & 26 & 11.1 \\
\hline & Kpando & Site 4 & 7 & 0 & 0 & 0 & 18 & 0 \\
\hline & VeGolokuate & Site 5 & 6 & 59 & 32.12 & 0 & 25 & 32.12 \\
\hline & Gbefi & Site 6 & 6 & 59 & 55.1 & 0 & 22 & 53.8 \\
\hline \multirow[t]{8}{*}{ Volta } & Aveyime & Site 1 & 6 & 16 & 29.937 & 0 & 30 & 30.102 \\
\hline & “ & Site 2 & 6 & 9 & 9.244 & 0 & 22 & 29.407 \\
\hline & “ & Site 3 & 6 & 16 & 23.277 & 0 & 34 & 27.315 \\
\hline & “ & Site 4 & 6 & 11 & 11.984 & 0 & 20 & 5.919 \\
\hline & “ & Site 5 & 6 & 16 & 23.277 & 0 & 34 & 27.315 \\
\hline & “ & Site 6 & 6 & 10 & 59.999 & 0 & 28 & 0.001 \\
\hline & “ & Site 7 & 5 & 39 & 13.319 & 0 & 10 & 3.378 \\
\hline & “ & Site 8 & 5 & 53 & 45.002 & 0 & 31 & 7.297 \\
\hline \multirow[t]{11}{*}{ Eastern } & Kpong & Site 1 & 6 & 7 & 58.419 & 0 & 4 & 28.995 \\
\hline & “ & Site 2 & 6 & 7 & 57.037 & 0 & 4 & 18.439 \\
\hline & “ & Site 3 & 6 & 7 & 58.352 & 0 & 4 & 25.987 \\
\hline & “ & Site 4 & 6 & 26 & 7.581 & 0 & 2 & 53.903 \\
\hline & “ & Site 5 & 6 & 24 & 19.981 & 0 & 3 & 51.505 \\
\hline & “ & Site 6 & 6 & 8 & 12.267 & 0 & 4 & 26.804 \\
\hline & “ & Site 7 & 6 & 8 & 12.348 & 0 & 4 & 27.368 \\
\hline & “ & Site 8 & 6 & 7 & 59.8 & 0 & 5 & 38.2 \\
\hline & “ & Site 9 & 6 & 7 & 57.7 & 0 & 4 & 24.1 \\
\hline & “ & Site 10 & 6 & 7 & 58.7 & 0 & 4 & 16.6 \\
\hline & “ & Site 11 & 6 & 7 & 52.4 & 0 & 4 & 42.9 \\
\hline \multirow{5}{*}{$\begin{array}{l}\text { Greater- } \\
\text { Accra }\end{array}$} & Dawenya & Site 1 & 5 & 53 & 38.99 & 0 & 11 & 20 \\
\hline & $“$ & Site 2 & 5 & 51 & 35.474 & 0 & 10 & 0.761 \\
\hline & “ & Site 3 & 5 & 51 & 27.54 & 0 & 10 & 11.528 \\
\hline & “ & Site 4 & 5 & 46 & 41.012 & 0 & 5 & 53.348 \\
\hline & $" 6$ & Site 5 & 5 & 46 & 34.082 & 0 & 4 & 1.643 \\
\hline
\end{tabular}

into a beaker and then transferred into another clean centrifuge tube to a volume of $10 \mathrm{ml}$.

Nematode extraction from rice roots. This was done using the root maceration and Bearman funnel method. The soil particles remaining on the roots after these were pulled from the soil were washed off as much as possible under running water to ensure that nematodes recovered using this method were solely from the roots. About $10 \mathrm{~g}$ of the fresh roots were weighed and cut into $1 \mathrm{~cm}$ pieces each. The root pieces were blended twice for each 5 seconds round. The nematodes were 
extracted using a modified Baermann method for $48 \mathrm{hr}$ (Hooper, 1990). The funnel was filled with about $100 \mathrm{ml}$ water to ensure that it touched the mesh to encourage movement of nematodes into the water. The set up was left for about 48 hours and the water which contained the extracted nematodes was drained into a $100 \mathrm{ml}$ glass beaker. The solution was sieved through 500 mesh sieve and the trapped nematodes in the solution were poured into another beaker and then transferred into a clean centrifuge tube for storage at $4^{\circ} \mathrm{C}$ until counted and identified.

Nematode count and identification. Nematodes were counted from three aliquots of $2 \mathrm{ml}$ subsample from a $25 \mathrm{ml}$ sample. Nematodes were identified to the genus level; and population densities were expressed as number of nematodes per10 $\mathrm{g}$ of fresh root and $200 \mathrm{~cm}^{3}$ of soil.

Relative abundance of nematode populations. Population density (PD) of nematodes per $200 \mathrm{~cm}^{3}$ of soil and $10 \mathrm{~g}$ plant root samples, and relative abundance (RA\%) were calculated according to Norton (1978) as follows: $\mathrm{PD}=$ average number of nematodes per $200 \mathrm{~cm}^{3}$ of soil and $10 \mathrm{~g}$ plant root samples, RA\% $=$ the number of individuals of a nematode genus or species / the total number of nematodes identified and counted from 200 $\mathrm{cm}^{3}$ soil or $10 \mathrm{~g}$ rice root $\times 100$.

\section{RESULTS}

Twenty-four nematode genera were identified in combined soil and root sample extractions from the Volta, Eastern and Greater Accra regions. These included: Aphelenchus spp., Belonolaimus spp., Ditylenchus spp., Dolichodorus spp., Helicotylenchus spp., Hemicriconemoides spp. Hemicycliophora spp. Heterodera spp., Hirschmaniella spp., Hoplolaimus spp., Longidorus spp., Meloidogyne spp., Paralongidorous spp., Paratylenchus spp., Pratylenchus spp.,
Radopholus spp., Rhabditida spp., Rotylenchulus spp., Scutellonema spp., Trichodorus spp., Tylenchornchus spp., Tylenchulus spp., Tylenchus spp. and Xiphinema spp.

Nematodes in soil and plant roots in Volta region. Sixteen nematode genera were encountered in the soils of the various locations (Table 2). A total of 517 nematodes were recovered from the soil samples. Aveyime had the most nematodes (387) compared to all other locations combined (130). The highest population densities of Pratylenchus spp. (40) and Scutellonema spp. (20) were found in one location (Tsawornu) in the Volta region. The highest population densities of Tylenchus spp. (41) was found in site 6 and site 7 in Aveyime. The highest population densities of Heterodera spp. (13) and Aphelenchus spp. (11) were found in site 1 in Aveyime. The highest population densities of Meloidogyne spp. (16) and Tylenchulus spp. (14) were found in site 8 in Aveyime. No nematodes were recovered from Akrofi and Gbefi communitues. Fewer nematode were found in Sardzikorfe (9) and Vegolokuate (11) compared to other locations. In the Volta region, Tylenchus spp. (29.0\%) and Pratylenchus spp. (17.79\%), were the most abundant in the soil. Low relative abundance was observed for Belonolaimus spp (0.4\%) Ditylenchus spp. (1.0\%) Hirschmaniella spp. (0.6\%) Rhabditida spp. (0.2\%) Rotylenchus spp. (0.2\%) Trichodorus spp $(0.8 \%)$ (Table 2).

A total of 632 nematodes were recovered from the root samples, with Gbefi having the largest number (220) among the study locations.In the Volta region, twelve and sixteen nematode genera were encountered in the roots and soils of rice from the various locations respectively (Table 2).

Meloidogyne spp. occurred in the largest quantities in roots and particularly in Gbefi, Tsawornu and Kpando; with 100, 50 and 42 second-stage juveniles (J2) per $10 \mathrm{~g}$ roots, respectively. The highest population densities 
TABLE 2. Relative abundance of nematode genera in $200 \mathrm{cc}$ soil and $10 \mathrm{~g}$ roots of rice from fourteen locations/sites in the Volta region

\begin{tabular}{lclllll}
\hline Nematode genera & $\begin{array}{c}\text { Population } \\
\text { density }\end{array}$ & $\begin{array}{c}\text { Relative } \\
\text { abundance }\end{array}$ & $\begin{array}{l}\text { Population } \\
\text { density }\end{array}$ & $\begin{array}{l}\text { Relative } \\
\text { abundance }\end{array}$ & Total & Relative \\
& $(200 \mathrm{cc}$ soil $)$ & $(200 \mathrm{cc}$ soil $)$ & $(10 \mathrm{~g} \mathrm{root})$ & $(10 \mathrm{~g}$ root $)$ & (Soil +Roots $)$ & (Soil+Root)
\end{tabular}

\begin{tabular}{|c|c|c|c|c|c|c|}
\hline Aphelenchus spp. & 19 & 3.7 & 0 & 0.0 & 19 & 1.7 \\
\hline Belonolaimus spp. & 2 & 0.4 & 0 & 0.0 & 2 & 0.2 \\
\hline Ditylenchus spp. & 5 & 1.0 & 39 & 6.2 & 44 & 3.8 \\
\hline Helicotylenchus spp. & 25 & 4.8 & 3 & 0.5 & 28 & 2.4 \\
\hline Heterodera spp. & 33 & 6.4 & 79 & 12.5 & 112 & 9.7 \\
\hline Hirschmaniella spp. & 3 & 0.5 & 60 & 9.5 & 63 & 5.5 \\
\hline Meloidogyne spp & 46 & 8.9 & 233 & 36.8 & 279 & 24.3 \\
\hline Paratylenchus spp & 12 & 2.3 & 168 & 26.5 & 180 & 15.7 \\
\hline Pratylenchus spp. & 92 & 17.8 & 4 & 0.6 & 96 & 8.4 \\
\hline Radopholus spp. & 0 & 0.0 & 1 & 0.2 & 1 & 0.1 \\
\hline Rhabditida spp. & 1 & 0.2 & 0 & 0.0 & 1 & 0.1 \\
\hline Rotylenchus spp. & 1 & 0.2 & 0 & 0.0 & 1 & 0.1 \\
\hline Scutellonema spp. & 65 & 12.6 & 32 & 5.1 & 97 & 8.4 \\
\hline Trichodorus spp & 4 & 0.8 & 0 & 0.0 & 4 & 0.3 \\
\hline Tylenchulus spp. & 39 & 7.5 & 1 & 0.2 & 40 & 3.5 \\
\hline Tylenchus spp & 150 & 29.0 & 10 & 1.6 & 160 & 13.9 \\
\hline Xphinema spp. & 20 & 3.9 & 2 & 0.3 & 22 & 1.9 \\
\hline Total & 517 & 100 & 632 & 100 & 1149 & 100 \\
\hline
\end{tabular}

of Pratylenchus spp. in roots were also found in Gbefi, and Kpando with 80 and 42 nematodes per $10 \mathrm{~g}$ roots respectively. Similarly, the highest population densities of Hirshmaniella spp. in roots were found in Gbefi, Tsawornu and Kpando with 10, 20 and 28 nematodes per $10 \mathrm{~g}$ roots respectively. Ditylenchus spp.was also found in $10 \mathrm{~g}$ roots from Gbefi (10), Tsawornu (10), Kpando (14), VeGolokuate (3) and Aveyime (2). Heterodera spp.was found in $10 \mathrm{~g}$ roots from Tsawornu (40), Kpando (35) and Aveyime (4).

Relative abundance (\%) of nematodes varied in the roots, Meloidogyne spp. (36.9\%) were the most abundant, followed by Paratylenchus spp. (26.58\%), Heterodera spp. (12.5\%), Hirschmaniella spp. (9.5\%) Ditylenchus spp. (6.2\%) and Scutellonema spp. $(5.1 \%)$. Low relative abundance was recorded forTylenchulus spp. (0.2\%),
Helicotylenchus spp. (0.5\%) Xphinema spp. (0.3\%), Pratylenchus spp. (0.6\%) and Radopholus spp. (0.2\%). Meloidogyne spp. $(24.3 \%)$ was therefore the most abundant nematode, and Paratylenchus spp. (15.7\%), Tylenchus spp. (13.9\%), and Heterodera spp. $(9.7 \%)$ had their relative abundances in this order (Table 2).

Nematodes in soil and plant roots in Dawhenya region. Sixteen nematode genera were found in Dawhenya (Table 3). A total of 858 nematodes were recovered from the soil samples. Site 5 (285) and site 1 (220) had the most nematodes compared to other locations. The highest population densities of Meloidogyne spp. (90) and Longidorus spp. (65) were found in site 1 in Dawhenya. Site5 had the highest population densities of Tylenchulus spp. (55), Ditylenchus spp. (15) 
TABLE 3. Relative abundance of nematode genera in $200 \mathrm{cc}$ soil and $10 \mathrm{~g}$ roots of rice from five sites in Dawhenya, Greater Accra region

\begin{tabular}{|c|c|c|c|c|c|c|}
\hline Nematode genera & $\begin{array}{l}\text { Population } \\
\text { density } \\
\text { (200 cc soil) }\end{array}$ & $\begin{array}{l}\text { Relative } \\
\text { abundance } \\
\text { (200 cc soil) }\end{array}$ & $\begin{array}{l}\text { Population } \\
\text { density } \\
\text { (10 g root) }\end{array}$ & $\begin{array}{l}\text { Relative } \\
\text { abundance } \\
\text { (10 g root) }\end{array}$ & $\begin{array}{l}\text { Total } \\
\text { population } \\
\text { (Soil +Roots) }\end{array}$ & $\begin{array}{l}\text { Relative } \\
\text { abundance } \\
\text { (Soil+Root) }\end{array}$ \\
\hline Aphelenchus spp. & 5 & 0.6 & 0 & 0.0 & 5 & 0.5 \\
\hline Ditylenchus spp. & 25 & 2.9 & 10 & 6.3 & 35 & 3.5 \\
\hline Hemicriconemoides & spp. 15 & 1.8 & 5 & 3.2 & 20 & 2.0 \\
\hline Hemicycliophora spp & p. $\quad 5$ & 0.6 & 5 & 3.2 & 10 & 1.0 \\
\hline Heterodera spp. & 80 & 9.4 & 40 & 25.3 & 120 & 11.9 \\
\hline Hirschmaniella spp. & 15 & 1.8 & 5 & 3.2 & 20 & 2.0 \\
\hline Longidorus spp. & 90 & 10.6 & 0 & 0.0 & 90 & 8.9 \\
\hline Meloidogyne spp. & 230 & 26.9 & 10 & 6.3 & 240 & 23.7 \\
\hline Paratylenchus spp. & 10 & 1.2 & 5 & 3.2 & 15 & 1.5 \\
\hline Pratylenchus spp. & 50 & 5.9 & 10 & 6.3 & 60 & 5.9 \\
\hline Rotylenchulus spp. & 25 & 2.9 & 0 & 0.0 & 25 & 2.6 \\
\hline Scutellonema spp. & 30 & 3.5 & 0 & 0.0 & 30 & 2.9 \\
\hline Trichodorus spp. & 30 & 3.5 & 0 & 0.0 & 30 & 2.9 \\
\hline Tylenchulus spp. & 133 & 15.5 & 22 & 13.9 & 155 & 15.3 \\
\hline Tylenchus spp. & 65 & 7.6 & 41 & 25.9 & 106 & 10.5 \\
\hline Xiphinema spp. & 45 & 5.3 & 5 & 3.2 & 50 & 4.9 \\
\hline Total & 853 & 100 & 158 & 100 & 1011 & 100 \\
\hline
\end{tabular}

Heterodera spp. (30) Hirschmaniella spp. (10) Pratylenchus spp. (25) Trichodorus spp. (15) and Xiphinema spp. (30). Aphelenchus spp. and Hemicycliophora spp. was found in a single location only (site 2 and site 5 respectively). Site 4 had the least number (83) of nematodes.In Dawhenya, Greater Accra region, Meloidogyne spp. (27\%)and Tylenchulus spp. (15.6\%), were the most abundant in the soil (Table 3).

Within the rice roots, Tylenchus spp. $(25.9 \%)$ were the most abundant, and Heterodera spp. (25.3\%) and Tylenchulus spp. (13.9\%) had their relative abundances in this order. Meloidogyne spp., Pratylenchus spp., and Ditylenchus spp. each had relative abundances of $6.3 \%$. Low relative abundances for Hemicriconemoides spp., Hemicycliophora spp., Hirschmaniella spp., Paratylenchus spp. and Xiphinema spp., (3.2\%) were observed.

A combination of soil and root nematodes, showed Meloidogyne spp. (23.7\%) as the most abundant, and Tylenchulus spp. (15.7\%), Heterodera spp. (11.9\%). Tylenchus spp. (10.5\%), and Longidorus spp. (8.9\%) had their relative abundances in this order. Low relative abundance for Aphelenchus spp. (0.5\%), Hemicycliophora spp. (1.9\%) and Paratylenchus spp. (1.5\%) were observed (Table 3).

Nematodes in soil and plant roots in SIREC region. Eleven genera of plant-parasitic nematodes were found in soil samples obtained from SIREC, Kpong (Table 4), thus giving a maximum number of 691 nematodes. Site 8 (178) and site 9 (108) had the most nematodes in their soils, compared to the other locations. The maximum population densities of Meloidogyne spp. (101) and Scutellonema spp. (61) were found in site 8 . The highest nematode numbers for Ditylenchus spp. (11), and Dolichodorus spp. (6) were from sites 7 and 1 respectively. However, the the highest 
TABLE 4. Relative abundance of nematode genera in $200 \mathrm{cc}$ soil and $10 \mathrm{~g}$ roots of rice from eleven locations in SIREC, Kpong, Eastern region

\begin{tabular}{|c|c|c|c|c|c|c|}
\hline Nematode spp. & $\begin{array}{l}\text { Population/ } \\
200 \mathrm{~g} \text { soil }\end{array}$ & $\begin{array}{c}\text { Relative } \\
\text { abundance }\end{array}$ & $\begin{array}{l}\text { Population/ } \\
10 \text { g roots } \\
\text { soil }(\%)\end{array}$ & $\begin{array}{l}\text { Relative } \\
\text { Abundance } \\
\text { roots (\%) }\end{array}$ & $\begin{array}{c}\text { Population } \\
\text { density } \\
\text { (soil + roots) }\end{array}$ & $\begin{array}{l}\text { Relaive } \\
\text { abundance } \\
\text { (soil+roots) }\end{array}$ \\
\hline Aphelenchus spp. & 1 & 0.1 & 18 & 2.1 & 19 & 1.2 \\
\hline Ditylenchus spp. & 13 & 1.9 & 2 & 0.2 & 15 & 1.0 \\
\hline Dolichodorus spp. & 6 & 0.9 & 0 & 0.0 & 6 & 0.4 \\
\hline Heterodera spp. & 22 & 3.2 & 44 & 5.0 & 66 & 4.2 \\
\hline Hirshmaniella spp. & 39 & 5.8 & 8 & 0.9 & 47 & 3.0 \\
\hline Hoplolaimus spp. & 5 & 0.7 & 1 & 0.1 & 6 & 0.4 \\
\hline Meloidogyne spp. & 280 & 40.6 & 234 & 26.9 & 514 & 32.9 \\
\hline Paralongidorus spp. & 0 & 0.0 & 2 & 0.2 & 2 & 0.1 \\
\hline Pratylenchus spp. & 1 & 0.1 & 306 & 35.1 & 307 & 19.6 \\
\hline Radopholus spp. & 0 & 0.0 & 71 & 8.2 & 71 & 4.6 \\
\hline Scutellonema spp. & 206 & 29.9 & 92 & 10.6 & 298 & 19.2 \\
\hline Tylenchorynchus spp. & 0 & 0.0 & 7 & 0.8 & 7 & 0.4 \\
\hline Tylenchus spp. & 116 & 16.8 & 82 & 9.4 & 198 & 12.7 \\
\hline Xiphenema spp. & 0 & 0.0 & 4 & 0.5 & 4 & 0.3 \\
\hline Total & 689 & 100 & 871 & 100 & 1560 & 100 \\
\hline
\end{tabular}


population densities of Hirschmaniella spp. (13) and Tylenchus spp. (22). were from site 4. Lower numbers of Aphelenchus spp. (1), Ditylenchus spp. (6) Hoplolaimus spp. (5) Pratylenchus spp. (2) Xiphinema spp. (2). were also extracted from the soils.

Nematode population densities of soil samples varied from the various sampling sites in SIREC, Kpong. Meloidogyne spp. (40.6\%) was found to be the most abundant in the soil. Scutellonema spp. (29.9\%) and Tylenchulus spp. (16.8\%) had the next highest abundances. Low relative abundances were observed for Aphelenchus spp. (0.1\%), Dolichodorus spp. (0.9\%), Ditylenchus spp. (1.9\%), Hoplolaimus spp. $(0.7 \%)$ and Pratylenchus spp. $(0.1 \%)$ respectively (Table 4 ).

Within the roots, Pratylenchus spp. $(35.1 \%)$ were the most abundant, and Meloidogyne spp. (26.9\%), Scutellonema spp. (10.6\%), Tylenchus spp. (9.4\%), and Radopholus spp. (8.2\%) had their relative abundances in this order. Very low relative abundances less than $5 \%$ were observed for Ditylenchus spp. (0.2\%), Hirshmaniella spp. $(0.9 \%)$, Hoplolaimus spp. (0.1\%) and Paralongidorus spp. (0.2\%). Combination of soil and root nematodes showed Meloidogyne spp. $(32.9 \%)$ as the most abundant, and Pratylenchulus spp. (19.6\%) Scutellonema spp. (19.2\%) and Tylenchus spp. (12.7\%) with relative abundances in this order. Comparatively low relative abundances of less than 5\%, for Aphelenchus spp. (1.2\%), Ditylenchus spp. (1.0\%) Dolichodorus spp. (0.4\%) Heterodera spp. (4.2\%) Hirshmaniella spp. (3.0\%) Hoplolaimus spp. (0.4\%) Paralongidorus spp. (0.1\%) Tylenchorynchus spp. $(0.4 \%)$ were observed (Table 4$)$.

\section{DISCUSSION}

Results of this survey demonstrate that a diversity of nematode genera is present in rice fields in Ghana. Twenty-four nematode genera were identified in soil and root samples from the Volta, Eastern and Greater Accra regions.
More than 200 species of plant-parasitic nematodes have been reported to be associated with rice, however, only a few of them are considered economically important pests of rice (Kyndt et al., 2014). Some of them such as the white tip nematode (Aphelenchoides besseyi), rice root knot (Meloidogyne graminicola), rice root (Hirschmanniella spp.), rice stem (Ditylenchus angustus), rice cyst (Heterodera oryzicola) and root lesion (Pratylenchus spp.) nematodes are economically most important. Some of these nematodes were found in our study.

A survey conducted between 1994 and 1997 in Ghana on rice fields in the forest zone (Ashanti, Brong Ahafo, and Eastern regions) and the savannah zone (Northern and Upper East regions) showed the presence of most of these nematodes (Coyne et al., 1999). These included Aphelenchus spp., Ditylenchus spp., Helicotylenchus spp., Heterodera spp., Hirschmaniella spp. Hoplolaimus spp., Meloidogyne spp., Paralongidorus spp., Paratylenchus spp.Pratylenchus spp., Rotylenchulus spp., Scutellonema spp., Tylenchoryhnchus spp. Tylenchus spp. Trichodorus spp.,and Xiphinema spp. Other nematode species identified by Coyne et al. (1999) were: Aphelenchoides spp. Criconemoides spp., and Rotylenchus spp. These nematodes were, however, absent in our study. Babatola (1984) reported that root-knot nematode, Meloidogyne spp. and the root lesion nematode, Pratylenchus spp. have both been observed to be parasitic nematodes on rice and reduce rice yields, both of these nematodes were identified in our studies. Hirshmaniella spp. Heterodera spp., Meloidogyne spp., and Pratylenchus spp. have been reported as the most important root nematodes by Bridge et al. (2005).

In the present study, Meloidogyne spp., and Pratylenchus spp. were most abundant in both soil and roots of rice plants. These nematodes are therefore of importance in rice cultivation in Ghanaian fields, and their population densities in soils should be managed 
effectively. In another study conducted in Ecuador, Meloidogyne graminicola was the most widespread and abundant nematode, occurring in both rainfed lowland and irrigated areas under rice cultivation (Triviño et al., 2016). This nematode has also been reported to cause damage in rice plantations from the Philippines (Prot et al., 1994), Bangladesh (Munir et al., 2002), Nepal (Padgham et al., 2004), Pakistan (Pokharel et al., 2005), and Costa Rica (Soriano et al., 2000). Coyne et al. (1999) have also observed that Pratylenchus spp. was more prevalent in rice fields that had been continuously cultivated for years.

The rice fields in Aveyime have been used in rice cultivation for many years, thus the association of Meloidogyne and Pratylenchus spp. with rice in this area. In a study conducted by Udo et al. (2011), Meloidogyne spp. was absent in the roots, but present in the soil. In the current study, however, Meloidogyne spp. was identified in both root and soil samples. According Pascual et al. (2014), Hirshmaniella spp. are the most common nematodes on irrigated rice fields, with a long history of rice farming where watering of plants was regular. However, in our studies Hirshmaniella spp. population densities were generally low. The low populations of this nematode if managed properly through land and crop rotations, together with tolerant varieties will prevent yield losses from these nematodes which have been observed in for e.g., China reaching 30\% (Liao et al., 2000).

Coyne et al. (1998) in a study in Ivory Coast identified Helicotylenchus spp. (100\%) and Pratylenchus spp. (96\%) as the most prevalent nematode genera in the forestsavanna zone and savannah zone respectively. The present study, however, revealed Meloidogyne spp. as the most prevalent nematode in both root and soil samples, however low populations of Helicotylenchus spp. $(2.4 \%)$ in both roots and soil samples were observed from the Volta region.A study by Talwana et al. (2008) showed that the nematode genera: Pratylenchus spp., Meloidogyne spp. and Helicotylenchus spp. occurred on all cereal crops.

Although the population densities of nematodes from the present survey were generally lower compared to nematode numbers recovered by other researchers, the interaction between nematodes and other plantpathogenic soil organisms, particularly fungi and bacteria, in the development of some disease complexes makes them very important even at very low densities.

\section{CONCLUSION}

Twenty-four nematode genera were identified in root and soil samples from the three regions in Ghana. Nematode spread and distribution among the three regions varied in both root and soil samples. Meloidogyne spp. was the most abundant nematode in soil planted to rice in Dawhenya and Eastern regions respectively, and the most abundant nematode in roots of rice samples from Volta region. The rice nematode Hirschmaniella spp. were generally low in both soil and root samples for the three regions. Management of nematode populations below specific threshold in rice cultivation is necessary through land rotations and fallowing.

\section{REFERENCES}

Amatekpor, J.K. and Dowuona, G.N.N. 1995. Site characterization. IBSRAM Vertisol Project. Department of Soil Science Publication. Technical Report No 95/001, University of Ghana, Legon, Ghana. 42pp. Babatola, J.O. 1984. Rice nematode problems in Nigeria: their occurrence, distribution and pathogenesis. Tropical Pest Management 30:256-265.

Bureau of Agricultural Statistics,2010, Crops statistics of the Philippines 2005-2009. National and Regional Statistics, Philippines. 
Bernier, J., Kumar, A., Serraj, R., Spaner, D. and Atlin, G. 2008. Review breeding upland rice for drought resistance. Journal of the Science of Food and Agriculture 88:927939.

Bridge, J., Plowright, R. A. and Peng, D. 2005. Nematode parasites of rice. In: Luc, M. Sikora, R.A and Bridge, J. (Eds.). Plantparasitic nematodes in subtropical and tropical Agriculture, Second edition. CAB International U.K. pp. 87-130

Coyne, D.L., Plowright, R.A., Thio, B.and Hunt, J.D. 1998, Plant-parasitic nematode diversity and prevalence in traditional upland rice in Ivory Coast; Preliminary observation on the effects of the cropping intensification. Fundamental Applied Nematology 21(6):723-732

Coyne, D.L., Plowright, R.A., Twumasi, J. and Hunt, D.J. 1999, Prevalence of plantparasitic nematodes associated with rice in Ghana with a discussion of their importance. Nematology 1(14):399-405

Gerber K., Smart, G.C. and Esser, R.P.1987. A comprehensive catalogue of plantparasitic nematodes associated with aquatic and wetland plants. Technical Bulletin 871 . Agricultural Experiment Station, Institute of Food and Agricultural Sciences, University of Florida, Gainesville, Florida, USA. 55pp.

Juliano, B.O. 1994. Rice chemistry and technology.The American Association of Cereal Chemists, Inc. St. Paul, Minnesota, USA $2^{\text {nd }}$ Printing [ A comprehensive review of all aspects of rice grain chemistry].

Hooper, D.J. 1990. Extraction and processing of plant and soil nematodes: In: Luc, M.S., Sikora, R.A. and Bridge, J. (Eds.), Plantparasitic nematodes in subtropical and tropical agriculture. Wallingford: $\mathrm{CAB}$ International. pp. 45-68.

Kyndt, T., Fernandez, D. and Gheysen, G. 2014. Plant parasitic nematode infections in rice: molecular and cellular insights. Annual Review of Phytopathology 52:7.17.19.
Munir, A., Pokharel, R.R. and Bridge, J. 2002. Nematode management in subsistence farmingin Bangladesh, Nepal and Pakistan. Nematology 4:136-137.

Norton, D.C. 1978. Ecology of plant-parasitic nematodes. John Wiley \& Sons. New York, NY, USA. pp. 31- 39.

Padgham, J.L., Duxbury, J.M., Mazid, A.M., Abawi, G.S. and Hossain, M. 2004. Yield losses by Meloidogyne graminicola on lowland rain fed rice in Bangladesh. Journal of Nematology 36:42-48.

Pascual, M.L.D., Decraemer, W., Tandigan, D., Lay, J., Viersteat, A., Steel, H. and Bert, W. 2014. Prevalence and characterization of plant- parasitic nematodes in lowland and upland rice Agro-ecosystems in Luzon, Phillipines. Nematropica 44:166-180.

Pokharel, R.R., Abawi, G.S., Smart, C.D. and Duxbury, J.M. 2005. Reproductive fitness of isolatesof Meloidogynegraminicolafrom Nepal onselected rice and wheat varieties. Journal of Nematology 37:388.

Prot, J.C., Soriano, I.R.S. and Matías, D.M. 1994. Major root-parasitic nematodes associated withirrigated rice in the Philippines. Fundamental and Applied Nematology 17:75-78.

Prot, J.C. and Rahman, M.L. 1994. Nematode ecology, economic importance, and management in rice ecosystems in South and Southeast Asia. Rice Pest Science and Management. pp.129-144.

Soriano, I.R., Prot, J.C. and Matías, D.M. 2000. Expression of tolerance for Meloidogyne graminicola in rice cultivars as affected by soil type and ûooding. Journal of Nematology 32:309-317.

Talwana, H.L., Butseya, M.M.and Tusiime, G. 2008. Occurrence of plant-parasitic nematodes and factors that enhance population build-up in cereal-based cropping systems in Uganda. African Crop Science Journal 16:115-131.

Tetteh, A.D. 2015. Plant-parasitic nematodes associated with rice at soil and irrigation research center (SIREC), BSc. 
Dissertation, Department of Crop Science Udo, I.O., Nneke, N.E. and Uyioata, A.M. University of Ghana, Ghana. 30pp. 2011. Survey of plant-parasitic nematodes Triviño, C., Navia-Santillán, D. and Velasco, L. 2016. Plant-parasitic nematodes associated with rice in Ecuador. Nematropica $46: 45-53$ associated with rice (Oryza sativa L.) in South Eastern Nigeria. African Journal of Plant Science 5(10):617-619. 